\title{
Anna Nowacka
}

Państwowa Wyższa Szkoła Zawodowa w Płocku

e-mail: anna.nowacka1@wp.pl

\section{RELACJE KLIENTÓW I CZŁONKÓW \\ Z BANKAMI SPÓŁDZIELCZYMI W KONTEKŚCIE ICH AKTYWNOŚCI SPOLECZNEJ \\ RELATIONS OF CUSTOMERS AND MEMBERS \\ WITH COOPERATIVE BANKS \\ IN THE CONTEXT OF THEIR SOCIAL ACTIVITY}

DOI: $10.15611 /$ pn.2018.532.22

JEL Classification: G21

Streszczenie: Celem opracowania jest ocena relacji klientów i członków z bankami spółdzielczymi. Autorka próbuje odpowiedzieć na pytania dotyczące aktywności udziałowców, opinii klientów na temat zakresu usług świadczonych przez banki spółdzielcze i ich społecznej aktywności. Podstawą empiryczną problematyki poruszonej w artykule jest studium literatury przedmiotu oraz wyniki badania ankietowego przeprowadzonego wśród 132 klientów wybranych banków spółdzielczych. Relacje banków spółdzielczych z klientami należy ocenić pozytywnie. Wyniki badań wskazują, że ponad 70\% klientów korzysta z usług jednego banku spółdzielczego. Prawie 69\% respondentów uważa, że zakres usług oferowany przez te instytucje jest odpowiedni. Klienci dostrzegają też społeczną aktywność banków spółdzielczych, chętnie uczestniczą w imprezach sponsorowanych. Pewien niepokój budzi fakt małej aktywności udziałowców. Tylko 1/3 z nich uczestniczy w zebraniach członków, a połowa udziałowców interesuje się sytuacją finansową banku spółdzielczego.

Słowa kluczowe: banki spółdzielcze, klienci, relacje klientów, aktywność społeczna.

Summary: The main objective of the study is to assess customers and members relations with cooperative banks. The author aims to answer the questions: regarding the activity of shareholders, customers' opinions on the range of services provided by cooperative banks and their social activity. The empirical basis is a literature study of the subject and results of a survey conducted among 132 customers of selected cooperative banks. The relations of cooperative banks with customers should be assessed positively. The results of the conducted research indicate that over $70 \%$ of customers use only services of one cooperative bank. Almost $69 \%$ of respondents believe that the range of the services offered by these institutions is appropriate. In addition, customers notice the social activity of cooperative banks and willingly participate in sponsored events. There is some concern about low shareholder activity. Only $1 / 3$ of them participate in the meetings of members, and half of shareholders are interested in the financial situation of the cooperative bank.

Keywords: cooperative banks, customers, customer relations, social activity. 


\section{Wstęp}

Najważniejszym elementem rynku usług bankowych jest klient, który powinien znajdować się w centrum zainteresowania banku. Dlatego też wszystkie działania podejmowane przez banki są ukierunkowane na klienta. Opinie klientów, ich postawy oraz zachowanie przyczyniają się do określenia pozycji konkurencyjnej danego banku.

Banki spółdzielcze jako niewielkie instytucje finansowe z kilkuprocentowym udziałem w rynku usług bankowych są najczęściej związane z małymi, lokalnymi społecznościami. Lokalny obszar działalności banków spółdzielczych obejmuje gminy, powiaty, miasta oraz sąsiadujące ze sobą terenowe jednostki administracyjne [Smoleń 2005, s. 12].

Dobra znajomość lokalnych warunków działania, środowiska i klientów, którzy są często udziałowcami banków spółdzielczych, pozwala lepiej tym instytucjom dostosować ofertę produktową do potrzeb zgłaszanych przez otoczenie. Niewątpliwym atutem banków spółdzielczych jest możliwość budowania silniejszych, opartych na zaufaniu relacji z klientami. Kreowanie więzi z klientami może wpływać pozytywnie na postrzeganie oferty produktowej oraz wizerunku banku spółdzielczego.

Klienci wybierający bank kierują się nie tylko wskaźnikami finansowymi, ale również motywami społecznymi i środowiskowymi. Coraz częściej szukają banku, który nie tylko w najlepszy sposób zaspokoi ich potrzeby, ale także będzie godny zaufania i powierzenia środków finansowych.

Aspekt zaufania jest niezwykle ważny w strategii banków spółdzielczych. Instytucje te, wykorzystując koncepcję społecznej odpowiedzialności biznesu, budują długotrwałe relacje z lokalnym środowiskiem i klientami. Wyróżnikiem banków spółdzielczych jest podejmowanie działań prospołecznych i proekologicznych. Motywacja klientów podejmujących decyzję o współpracy z bankiem spółdzielczym nie dotyczy tylko korzyści finansowych, ale również wizerunku i wiarygodności banku oraz jego aktywności społecznej.

\section{Charakterystyka klientów i członków banków spółdzielczych}

Głównymi klientami banków spółdzielczych są: społeczność lokalna, instytucje samorządowe, małe i średnie przedsiębiorstwa, rolnicy, lokalny przemysł i lokalne instytucje.

Gospodarstwa domowe, a w szczególności gospodarstwa rolne, mają znaczący udział w strukturze podmiotowej rynku obsługiwanego przez banki spółdzielcze. Banki spółdzielcze mają lepszą znajomość tego segmentu rynku aniżeli banki komercyjne. Rolnictwo jest naturalną bazą operacyjną banków spółdzielczych, bowiem mają one ugruntowaną pozycję wynikającą z doświadczenia i tradycji, usytuowania bliżej klienta oraz $\mathrm{z}$ racji pozostawania przez długi czas poza sferą zainteresowania banków komercyjnych [Nowakowska-Krystman 2006, s. 67]. Wie- 
le cech banków spółdzielczych sprzyja współpracy z gospodarstwami rolnymi. Szybkość i samodzielność w podejmowaniu decyzji, bliskość przestrzenna oraz duża liczba placówek, ponadto bogata oferta usług dla rolników to wybrane atuty spółdzielczego sektora bankowego obsługującego rolników.

Grupą, która jest traktowana prestiżowo przez banki spółdzielcze, są instytucje samorządowe ze względu na przewidywalność, jawność i przejrzystość gospodarki finansowej. Poza tym urzędy gminy lub powiatu przysparzają bankom spółdzielczym nowych klientów, np. szkoły, jednostki budżetowe, zakłady i przedsiębiorstwa komunalne, placówki ochrony zdrowia. Obszar tej współpracy jest przedmiotem konkurencji między bankami spółdzielczymi a komercyjnymi. Zdaniem A. Jakubowskiej [2015, s. 80, 81] banki komercyjne najczęściej współpracują z gminami miejskimi powyżej 40 tys. mieszkańców oraz z miastami na prawach powiatu do 100 tys. mieszkańców. Banki spółdzielcze z kolei, z uwagi na lokalny charakter, najczęściej współpracują z gminami wiejskimi i miejsko-wiejskimi.

Kolejną grupą klientów banków spółdzielczych są podmioty gospodarcze. Banki spółdzielcze odgrywają znaczącą rolę nie tylko w finansowaniu rolnictwa, ale również małej przedsiębiorczości. Rola ta sprowadza się nie tylko do finansowania, ale również do informowania klientów, zakładania i prowadzenia rachunków oraz udzielania gwarancji bankowych. Banki spółdzielcze biorą czynny udział w absorpcji środków finansowych z Unii Europejskiej [Rosa 2009, s. 117].

Charakterystyczną i najważniejszą częścią bankowości spółdzielczej są jej członkowie. Wszystkie prawa i obowiązki wynikające ze stosunku członkostwa są przypisane do danej osoby członka spółdzielni i nie mogą być przenoszone na osoby trzecie. Historycznie członkostwo w banku spółdzielczym było skoncentrowane na obsłudze dwóch grup zawodowych: rolników i rzemieślników. Obecnie dostęp do usług tych banków nie jest ograniczony. Członkiem banku może być osoba fizyczna o pełnej zdolności do czynności prawnych, spełniająca wymagania określone w statucie banku spółdzielczego.

Zaletą bycia udziałowcem banku spółdzielczego są korzyści o charakterze społeczno-gospodarczym. Członkostwo daje poczucie uczestniczenia w lokalnym życiu banku, w głównych jego wydarzeniach. Członkowie mają poczucie udziału w wartości spółdzielczej poprzez prawo głosu i wpływania na politykę banku. Możliwość uczestniczenia w wydarzeniach społecznych i akcjach charytatywnych promowanych przez bank daje poczucie bycia częścią podmiotu wspierającego lokalne życie.

Niestety w polskiej bankowości spółdzielczej członkostwo traci stopniowo znaczenie. Zmniejszenia liczby udziałowców można upatrywać również w aktualnych przepisach prawnych, które nie dopuszczają możliwości stosowania preferencyjnych warunków produktowych dla członków oraz w coraz rzadziej wypłacanych dywidendach.

Inną przyczyną jest zbyt mała popularyzacja wiedzy w zakresie korzyści wynikających z członkostwa w banku spółdzielczym. Klienci nie zawsze zdają sobie sprawę, że banki spółdzielcze umożliwiają członkom czynne uczestnictwo w orga- 
nach statutowych, a przez to realny wpływ na ich funkcjonowanie i kierunki rozwoju. Udziałowcy wykazują się pewną biernością i brakiem zainteresowania sytuacją w banku [Nowacka i in. 2017, s. 97-105].

\subsection{Aspekty etyczne budowania relacji banków spółdzielczych z klientami}

Immanentną cechą relacji między klientami a bankami, ważną i niezbywalną, podstawową wartością, jest kultura zaufania publicznego. Jest nieodłącznym atrybutem działania banku i warunkuje jego rozwój i przetrwanie [Masiukiewicz 2007, s. 4].

Banki spółdzielcze w relacjach z klientami starają się uwzględniać szczególne zaufanie, jakim są darzone, poprzez wysokie wymagania co do rzetelności i starannego traktowania wszystkich klientów. Podejmowanie działań w tym zakresie postulowane jest w zasadach dobrej praktyki bankowej. Jest to zbiór norm postępowania dotyczący działalności banków i odnoszący się do osób zatrudnionych w bankach oraz także do osób pośredniczących w czynnościach bankowych, tj. działających na rzecz banków i w ich imieniu [Strzelecki 2008, s. 115]. Zasady te zawierają:

- zasady postępowania banków z klientami,

- zasady wzajemnych stosunków między bankami,

- zasady reklamy, zasady postępowania pracowników banku,

- postanowienia dotyczące Komisji Etyki Bankowej wraz z załączonym regulaminem Komisji Etyki Bankowej.

Przestrzeganie zasad etycznych w praktyce bankowej powinno być realizowane poprzez uczciwą i przejrzystą ofertę bankową, rzetelny przekaz informacji zawartych w materiałach promocyjnych, bezstronne i uczciwe zasady załatwiania reklamacji oraz kształtowanie etycznych relacji z konkurencją [Nowacka 2016, s. 63].

\section{Społeczna aktywność banków spółdzielczych}

Banki spółdzielcze jako instytucje finansowe najczęściej zlokalizowane w małych miejscowościach, wyrażają wymiar społeczny swojej działalności poprzez dystrybucję produktów dla tej grupy klientów. Strategie działania tych banków obejmują kwestię zaspokajania potrzeb członków i klientów społeczności lokalnej, wspieranie inicjatyw lokalnych (np. kulturalnych, artystycznych czy sportowych), działania na rzecz rozwoju gospodarczego w wymiarze lokalnym lub regionalnym.

Wsparcie dla społeczności lokalnych ze strony banków spółdzielczych ma wymiar nie tylko finansowy. Banki te przeznaczają wypracowany zysk na rozmaite lokalne inicjatywy. Sponsorowanie młodych sportowców czy zespołów artystycznych, wsparcie dla lokalnych wydarzeń i upamiętnianie miejsc historycznych, promocja walorów turystycznych gminy - wszystkie te działania są dla banków spółdzielczych celem statutowym na równi z dystrybucją środków unijnych czy przygotowywaniem nowej oferty kredytowej. To odróżnia spółdzielców od dużych korporacji, dla których społeczna odpowiedzialność biznesu stanowi kwestię uboczną, niekiedy motywowaną przede wszystkim korzyściami natury wizerunkowej [Majka 2016, s. 54]. 
Często banki spółdzielcze posiadają oddział lub placówkę w małej miejscowości, słabo zaludnionej i o niskich dochodach mieszkańców, gdzie trudno znaleźć ekonomiczne uzasadnienie tej decyzji. W takim przypadku można mówić o realizacji celów społecznych instytucji. Funkcjonowanie w większych lub mniejszych miastach teoretycznie umożliwiałoby pozyskanie większej liczby klientów. Historycznie jednak banki spółdzielcze zlokalizowane były w małych miejscowościach.

Banki spółdzielcze oferują swoim klientom szeroki asortyment produktów bankowych. Oprócz najbardziej popularnych usług bankowych, takich jak: prowadzenie rachunków bieżących, rachunków oszczędnościowo-rozliczeniowych, kredytów obrotowych, inwestycyjnych i preferencyjnych, banki proponują również inne usługi. Jednak to, co odróżnia banki spółdzielcze od innych instytucji i wskazuje również na cel społeczny działalności, to oferowanie podstawowych produktów finansowych tym grupom społecznym, które nie mają dostępu lub mają utrudniony dostęp do usług komercyjnych instytucji bankowych. Takim przykładem są kredyty klęskowe i preferencyjne z dopłatą ze środków Agencji Restrukturyzacji i Modernizacji Rolnictwa, Banku Gospodarstwa Krajowego i Narodowego Funduszu Ochrony Środowiska i Gospodarki Wodnej.

Bankowość spółdzielcza, bazując na idei samopomocy i wzajemnego wsparcia oraz lokalnego charakteru swoich działań, przyczynia się do ograniczenia wykluczenia finansowego, w szerszym kontekście, wykluczenia społecznego. Są to instytucje głęboko zakorzenione w społeczności lokalnej świadczące usługi w obszarach wiejskich, rolnictwie, terenach mniej zurbanizowanych, gdzie stopień ubankowienia jest zdecydowanie mniejszy aniżeli w większych aglomeracjach oraz w sektorach pozarolniczych.

\section{Opinia klientów i członków na temat relacji z bankami spóldzielczymi}

Celem przeprowadzonego badania było poznanie opinii klientów i członków na temat: kształtowania się ich relacji z bankami spółdzielczymi, wiedzy i oceny działalności banku, oferty produktowej, a także aktywności społecznej.

Badanie ankietowe zostało przeprowadzone we wrześniu i październiku $2015 \mathrm{r}$. wśród klientów wybranych banków spółdzielczych, zlokalizowanych na terenie powiatu płockiego (województwo mazowieckie) i żywieckiego (województwo śląskie). Klienci objęci badaniem ankietowym zostali wybrani metodą doboru wygodnego [Hill, Alexander 2003, s. 126]. O wypełnienie kwestionariusza ankiety poproszeni zostali klienci, którzy wychodzili z banku i wyrażali chęć udzielenia odpowiedzi na zawarte w kwestionariuszu pytania. Łącznie przebadanych zostało 100 osób z województwa mazowieckiego i 32 z województwa śląskiego. Próba miała charakter niereprezentatywny. Obliczenia wykonano w programie IBM SPSS 23.0. Jako poziom istotności statystycznej przyjęto $p<0,05$. 
Większość badanych stanowiły kobiety (56,5\%). Pod względem wieku największy udział wśród ogółu respondentów miały osoby z grupy wiekowej 36-45 lat $(25,7 \%)$. Najliczniejszymi grupami ze względu na kryterium wykształcenia były grupy ankietowanych z wykształceniem wyższym zawodowym $(22,7 \%)$ oraz średnim zawodowym (21,9\%). Zdecydowana większość osób zamieszkiwała tereny wiejskie, w tym: wieś - 40,9\% i wieś gminną - 37,8\%. Ponad 44\% respondentów posiadało stałą pracę. $\mathrm{Z}$ reguły osoby te były rolnikami $(18,9 \%)$ i pracownikami fizycznymi (19,7\%). Największy odsetek osób (28\%) deklarował, że uzyskuje miesięczny dochód netto na osobę w przedziale 1001-1500 zł.

W pierwszej kolejności poproszono respondentów o określenie ich statusu: czy są klientami i udziałowcami banku spółdzielczego, czy tylko klientami. Z uzyskanych danych wynika, że członkowie stanowili $62,9 \%$ badanych ( 83 osoby). Pozostali to klienci, którzy nie wnieśli udziału do banku - 37,1\% (49 osób). Kolejne pytania dotyczyły aktywności klientów-udziałowców, ich wiedzy na temat sytuacji banku spółdzielczego. Wyniki przedstawiono w tab. 1.

Tabela 1. Uczestnictwo w zebraniach członków i przedstawicieli banku spółdzielczego

\begin{tabular}{|l|c|c|}
\hline $\begin{array}{c}\text { Czy bierze Pan/Pani udział } \\
\text { w zebraniach członków } \\
\text { i przedstawicieli banku } \\
\text { spółdzielczego? }\end{array}$ & $\begin{array}{c}\text { Liczba } \\
\text { odpowiedzi }\end{array}$ & Procent \\
\hline Tak & 29 & 34,9 \\
\hline Nie & 54 & 65,1 \\
\hline Brak odpowiedzi & 0 & 0 \\
\hline Ogółem & 83 & $\mathbf{1 0 0}$ \\
\hline
\end{tabular}

Źródło: opracowano na podstawie badania ankietowego.

Zaledwie 1/3 badanych udziałowców uczestniczy w zebraniach organizowanych przez banki spółdzielcze. Podczas tych spotkań prezentowane są wyniki finansowe banku oraz omawiane bieżące sprawy. Ta niska frekwencja na zebraniach członków świadczy o tym, że udziałowy nie chcą uczestniczyć w procesie decyzyjnym banku.

Tabela 2. Zainteresowanie sytuacją finansową banku spółdzielczego

\begin{tabular}{|l|c|c|}
\hline $\begin{array}{c}\text { Czy interesuje się Pan/Pani sytuacją } \\
\text { finansową banku spółdzielczego? }\end{array}$ & $\begin{array}{c}\text { Liczba } \\
\text { odpowiedzi }\end{array}$ & Procent \\
\hline Tak & 40 & 48,2 \\
\hline Nie & 21 & 25,3 \\
\hline Brak odpowiedzi & 22 & 26,5 \\
\hline Ogółem & 83 & 100 \\
\hline
\end{tabular}

Źródło: opracowano na podstawie badania ankietowego. 
Ogólne zainteresowanie sytuacją finansową banku spółdzielczy wykazywało ponad $48 \%$ ankietowanych członków. Większość tych osób wskazywała, że zapoznaje się ze sprawozdaniami finansowymi banku.

Tabela 3. Zainteresowanie sprawozdaniami finansowymi banku spółdzielczego

\begin{tabular}{|l|c|c|}
\hline $\begin{array}{c}\text { Czy miał Pan/Pani możliwość wglądu } \\
\text { do sprawozdań finansowych banku } \\
\text { spółdzielczego? }\end{array}$ & $\begin{array}{c}\text { Liczba } \\
\text { odpowiedzi }\end{array}$ & Procent \\
\hline Tak & 35 & 42,1 \\
\hline Nie & 22 & 26,5 \\
\hline Nie interesowałem się & 26 & 31,4 \\
\hline Ogółem & 83 & 100 \\
\hline
\end{tabular}

Źródło: opracowano na podstawie badania ankietowego.

Dość duża grupa klientów-udziałowców twierdziła, że nie ma dostępu do sprawozdań finansowych banku spółdzielczego $(26,5 \%)$ lub nie interesowała się tym $(31,4 \%)$. Niestety wyniki te potwierdzają małą aktywność członków banków spółdzielczych.

Kolejne pytania były skierowane do wszystkich klientów i dotyczyły oferty produktowej banku.

Tabela 4. Opinia klientów o zakresie oferowanych usług przez bank spółdzielczy

\begin{tabular}{|l|c|c|}
\hline $\begin{array}{c}\text { Czy uważa Pan/Pani, że zakres usług } \\
\text { oferowanych przez bank spółdzielczy } \\
\text { jest odpowiedni? }\end{array}$ & $\begin{array}{c}\text { Liczba } \\
\text { odpowiedzi }\end{array}$ & Procent \\
\hline Tak & 91 & 68,9 \\
\hline Nie & 4 & 3,0 \\
\hline Trudno ocenić & 36 & 27,3 \\
\hline Brak odpowiedzi & 132 & 0,8 \\
\hline Ogółem & 132 & 100 \\
\hline
\end{tabular}

Źródło: opracowano na podstawie badania ankietowego.

Zdecydowana większość ankietowanych klientów uważała, że zakres usług oferowanych przez bank spółdzielczy jest odpowiedni. Należy jednak zauważyć, że $27,3 \%$ respondentów nie miało zdania w tej sprawie. Może to wynikać z faktu, że korzystają z usług jednego banku i nie są w stanie porównać oferty. Tę tezę mogą potwierdzać wyniki zaprezentowane w kolejnych tabelach.

Dane zaprezentowane w tab. 5 wskazują, że miejsce zamieszkania respondentów ma wpływ na kształtowanie się opinii o ofercie banku spółdzielczego. Klienci z małych miast i miast powyżej 10 tysięcy mieszkańców najczęściej wyrażali się pozytywnie o zakresie usług banku. Natomiast klienci pochodzący z terenów wiej- 
Tabela 5. Wpływ miejsca zamieszkania na opinię klientów o zakresie oferowanych usług przez bank spółdzielczy

\begin{tabular}{|c|c|c|c|c|c|c|}
\hline \multirow{2}{*}{\multicolumn{2}{|c|}{$\begin{array}{c}\text { Czy uważa Pan/Pani, że zakres usług } \\
\text { oferowanych przez bank spółdzielczy } \\
\text { jest odpowiedni? }\end{array}$}} & \multicolumn{4}{|c|}{ Miejsce zamieszkania } & \multirow{3}{*}{$\begin{array}{c}\text { Ogółem } \\
88\end{array}$} \\
\hline & & \multirow{2}{*}{$\begin{array}{c}\text { Wieś } \\
39\end{array}$} & \multirow{2}{*}{$\begin{array}{c}\begin{array}{c}\text { Wieś } \\
\text { gminna }\end{array} \\
26\end{array}$} & \multirow{2}{*}{\begin{tabular}{c|}
$\begin{array}{c}\text { Małe miasto } \\
\text { (do } 10 \text { tys.) }\end{array}$ \\
12
\end{tabular}} & \multirow{2}{*}{$\begin{array}{c}\text { Miasto } \\
\text { (powyżej } 10 \text { tys.) } \\
11\end{array}$} & \\
\hline Tak & $N$ & & & & & \\
\hline & $\%$ & 72,2 & 52,0 & 92,3 & 100 & 68,7 \\
\hline \multirow[t]{2}{*}{$\mathrm{Nie}$} & $N$ & 3 & 1 & 0 & 0 & 4 \\
\hline & $\%$ & 5,6 & 2,0 & 0,0 & 0,0 & 3,2 \\
\hline \multirow[t]{2}{*}{ Trudno ocenić } & $N$ & 12 & 23 & 1 & 0 & 36 \\
\hline & $\%$ & 22,2 & 46 & 7,7 & 0,0 & 28,1 \\
\hline \multirow{2}{*}{$\begin{array}{l}\text { Ogółem uzyskanych } \\
\text { odpowiedzi }\end{array}$} & $N$ & 54 & 50 & 13 & 11 & 128 \\
\hline & $\%$ & 100 & 100 & 100 & 100 & 100 \\
\hline
\end{tabular}

$c^{2}=18,093 ; d f=6 ; p=0,006 ;$ test istotny przy $p<0,05$.

Źródło: opracowano na podstawie badania ankietowego.

skich istotnie częściej nie mieli zdania w tej sprawie: mieszkańcy wsi - 22,2\% oraz wsi gminnej - 46\%. Banki spółdzielcze bardzo często są jedynymi instytucjami finansowymi na terenach wiejskich. Dlatego też ich klienci nie mają zbyt wielu możliwości wyboru korzystania z usług bankowych.

Tabela 6. Wpływ obecnej sytuacji społeczno-zawodowej na opinię klientów o zakresie oferowanych usług przez bank spółdzielczy

\begin{tabular}{|l|c|c|c|c|c|c|c|c|}
\hline \multicolumn{2}{|c|}{$\begin{array}{c}\text { Czy uważa Pan/Pani, } \\
\text { że zakres usług oferowanych } \\
\text { przez bank spółdzielczy jest } \\
\text { odpowiedni? }\end{array}$} & $\begin{array}{c}\text { Mam } \\
\text { stałą } \\
\text { pracę }\end{array}$ & $\begin{array}{c}\text { Pracuję } \\
\text { dorywczo }\end{array}$ & $\begin{array}{c}\text { Jestem } \\
\text { bezrobotny }\end{array}$ & $\begin{array}{c}\text { Rencista/ } \\
\text { Emeryt }\end{array}$ & $\begin{array}{c}\text { Prowadzę } \\
\text { własną } \\
\text { działalność }\end{array}$ & $\begin{array}{c}\text { Jestem } \\
\text { studentem }\end{array}$ & Ogółem \\
\hline \multirow{2}{*}{ Tak } & $N$ & 42 & 2 & 9 & 16 & 15 & 5 & 88 \\
\cline { 2 - 10 } & $\%$ & 70,7 & 22,2 & 60,0 & 76,2 & 88,2 & 62,5 & 68,8 \\
\hline \multirow{2}{*}{ Nie } & $N$ & 1 & 0 & 2 & 0 & 1 & 0 & 4 \\
\cline { 2 - 10 } & $\%$ & 1,7 & 0,0 & 13,3 & 0,0 & 5,9 & 0,0 & 3,1 \\
\hline \multirow{2}{*}{ Trudno ocenić } & $N$ & 16 & 7 & 4 & 5 & 1 & 3 & 36 \\
\cline { 2 - 10 } & $\%$ & 27,6 & 77,8 & 26,7 & 23,8 & 5,9 & 37,5 & 28,1 \\
\hline \multirow{2}{*}{$\begin{array}{l}\text { Ogółem uzyskanych } \\
\text { odpowiedzi }\end{array}$} & $N$ & 58 & 9 & 15 & 21 & 17 & 8 & 128 \\
\cline { 2 - 10 } & $\%$ & 100 & 100 & 100 & 100 & 100 & 100 & 100 \\
\hline
\end{tabular}

$c^{2}=22,44 ; d f=10 ; p=0,013 ;$ test istotny przy $p<0,05$.

Źródło: opracowano na podstawie badania ankietowego.

Sytuacja społeczno-zawodowa ankietowanych istotnie wpłynęła na rozkład odpowiedzi. Klienci prowadzący własną działalność najczęściej udzielili odpowiedzi pozytywnie oceniającej ofertę banku spółdzielczego - 88,2\%. Osobom pracującym dorywczo najtrudniej było dokonać oceny $-77,8 \%$. 
Respondentom zadano kolejne pytanie dotyczące korzystania z usług bankowych w innym banku (tab. 7).

Tabela 7. Opinia klientów o korzystaniu z usług oferowanych przez inny bank

\begin{tabular}{|l|c|c|}
\hline \multicolumn{1}{|c|}{$\begin{array}{c}\text { Czy korzysta Pan/Pani } \\
\text { z usług innego banku? }\end{array}$} & $\begin{array}{c}\text { Liczba } \\
\text { odpowiedzi }\end{array}$ & Procent \\
\hline Tak & 36 & 27,3 \\
\hline Nie & 95 & 71,9 \\
\hline Brak odpowiedzi & 1 & 0,8 \\
\hline Ogółem & 132 & 100 \\
\hline
\end{tabular}

Źródło: opracowano na podstawie badania ankietowego.

Ponad 70\% ankietowanych klientów wykazało się wysokim stopniem lojalności poprzez korzystanie z usług bankowych tylko w banku spółdzielczym. Warto podkreślić, że część osób, które udzieliły odpowiedzi twierdzącej, korzysta z usług innego banku spółdzielczego, zlokalizowanego w tej samej lub sąsiedniej miejscowości.

Ważnym elementem, wpisanym w specyfikę banków spółdzielczych jest ich społeczna aktywność. Biznes społecznie odpowiedzialny przyczynia się niewątpliwie do zwiększenia wiarygodności i budowania kapitału społecznego. Istotną korzyścią jest również poprawa relacji z lokalnym otoczeniem oraz wzrost zaufania klientów. W tym kontekście poproszono respondentów o wyrażenie opinii w sprawie aktywności społecznej banków spółdzielczych (tab. 8).

Tabela 8. Opinia klientów na temat aktywności społecznej banków spółdzielczych

\begin{tabular}{|l|c|c|c|}
\hline $\begin{array}{c}\text { Czy banki spółdzielcze wspierają } \\
\text { inicjatywy społeczne? }\end{array}$ & Liczba & Procent \\
\hline Tak & & 75 & 56,8 \\
\hline Nie & & 50 & 37,9 \\
\hline Brak odpowiedzi & & 132 & 5,3 \\
\hline Ogółem & & 700 \\
\hline
\end{tabular}

Źródło: opracowano na podstawie badania ankietowego.

Ponad 50\% ankietowanych klientów uważało, że ich bank spółdzielczy wspiera lokalne inicjatywy społeczne. Przeciwnego zdania było $37,9 \%$ respondentów.

Silny związek banków spółdzielczych z interesami społeczności lokalnych zobowiązuje do wspierania ich inicjatyw. Poproszono ankietowanych klientów o wskazanie form tych przedsięwzięć (rys. 1).

Z uzyskanych odpowiedzi wynika, że banki spółdzielcze najczęściej dotują i promują imprezy kulturalno-oświatowe $(35,3 \%)$ oraz wspierają działalność organizacji społecznych i charytatywnych $-37 \%$. 


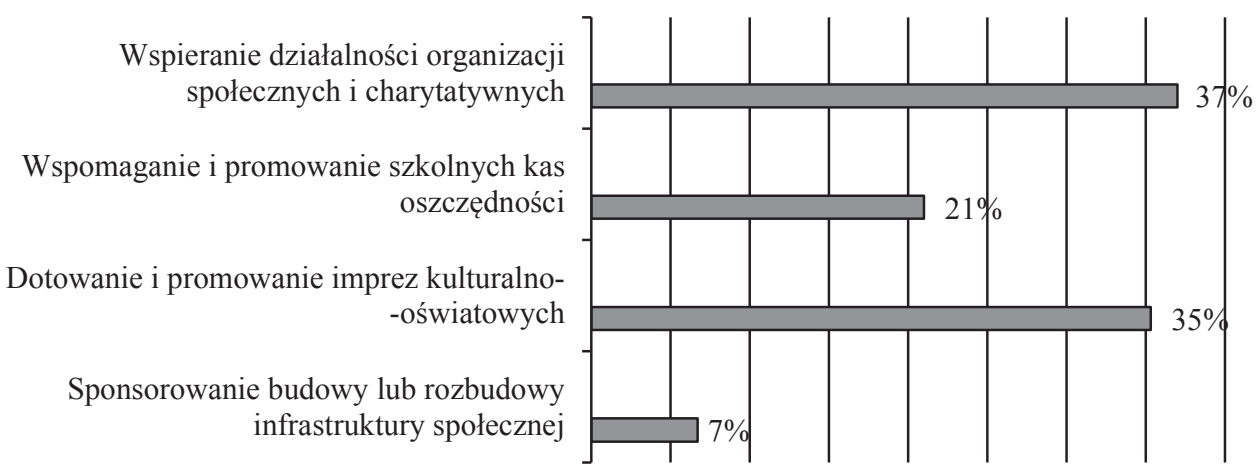

Rys. 1. Formy wspierania inicjatyw społecznych przez banki spółdzielcze według oceny klientów banków Źródło: opracowano na podstawie badania ankietowego.

Wachlarz imprez sponsorowanych przez banki spółdzielcze jest dosyć szeroki, a klienci chętnie w nich uczestniczą. Na rysunku 2 zaprezentowano odpowiedzi ankietowanych ze wskazaniem popularności, jaką cieszyły się poszczególne inicjatywy banków.

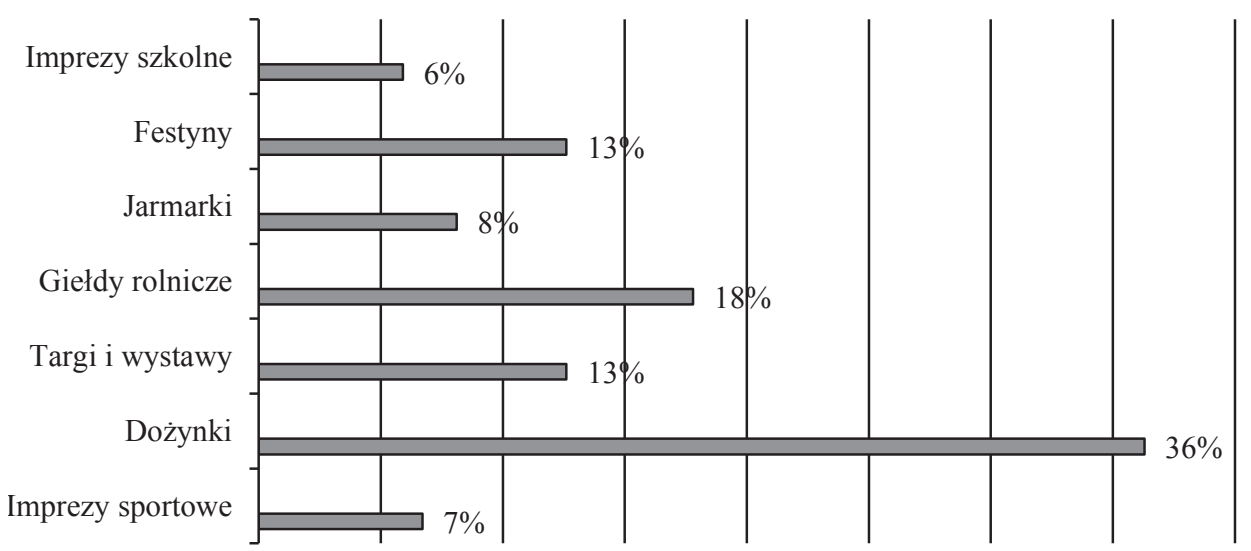

Rys. 2. Rodzaje imprez sponsorowanych przez banki spółdzielcze, w których uczestniczyli ich klienci Źródło: opracowano na podstawie badania ankietowego.

Respondenci najczęściej wskazywali dożynki - 36,3\% oraz giełdy rolnicze $17,8 \%$, a najrzadziej imprezy sportowe $-5,9 \%$. Lokalny charakter działalności oraz umiejscowienie banków spółdzielczych w małych miejscowościach na terenach wiejskich wyznaczają kierunek działań tych instytucji w obszarze społecznej aktywności. Jedną z najliczniejszych grup klientów spółdzielczego sektora bankowego są rolnicy i przedsiębiorcy z sektora rolno-spożywczego. Dlatego też zakres inicjatyw banków spółdzielczych jest skierowany do tych społeczności. 


\section{Zakończenie}

Banki spółdzielcze starają się wypełniać swoją misję społeczną poprzez dobre i trwałe relacje z klientami i członkami oraz poprzez działanie na rzecz środowiska lokalnego. Siłą tego sektora jest indywidualne podejście do klienta, umiejętność budowania relacji, w której klient rozpoznawany jest niemalże imiennie i tak obsługiwany.

Wyniki badań to odzwierciedlają. Prawie $69 \%$ respondentów pozytywnie ocenia zakres usług oferowanych przez banki spółdzielcze, najczęściej taką opinię prezentowały osoby prowadzące własną działalność gospodarczą (ponad 88\%).

Trzeba zauważyć, że prawie 3/4 ankietowanych klientów korzystało tylko $\mathrm{z}$ usług jednego banku. W przyszłości ten wskaźnik może być mniej korzystny, ponieważ młodsi klienci są bardziej wymagający, częściej korzystają z nowoczesnych kanałów dostępu do usług bankowych i są mniej lojalni.

Banki spółdzielcze powinny pogłębiać świadomość społeczności lokalnej, a zwłaszcza udziałowców dotyczącą związków między aktywnością w korzystaniu $\mathrm{z}$ usług przez te banki oferowanych, nadzorem nad ich działalnością, efektywnością funkcjonowania banku a ich poziomem życia. Niestety zbyt mała aktywność udziałowców powoduje, że instytucje te tracą obywatelski charakter prowadzonej działalności. Jednak problem nie leży tylko po stronie samych banków, ale również członków, którzy często wykazują pewną bierność i brak zainteresowania działalnością banku spółdzielczego i decyzjami, które są tam podejmowane. Tylko co trzeci ankietowany członek uczestniczył w zebraniach, a ok. $42 \%$ respondentów interesowało się sytuacją finansową banku spółdzielczego. Dlatego też ważnym aspektem z punktu widzenia społecznego wymiaru funkcjonowania banków spółdzielczych powinien być system zachęt dla udziałowców i uwypuklenie ich roli i wpływu na proces decyzyjny w banku.

Banki spółdzielcze podejmują szereg inicjatyw społecznych, co potwierdzają przeprowadzone badania. Często współfinansują imprezy kulturalne, oświatowe i sportowe; wspierają finansowo szkoły, przedszkola, kluby sportowe, ochotniczą straż pożarną, stowarzyszenia, biblioteki.

Badani dostrzegali i dosyć wysoko oceniali wizerunek banku jako instytucji społecznie aktywnej. To oznacza, że zaangażowanie banków spółdzielczych w działania o charakterze społecznym, wspieranie lokalnych inicjatyw jest pozytywnie odbierane przez klientów.

\section{Literatura}

Hill N., Alexander J., 2003, Pomiar satysfakcji i lojalności klientów, Oficyna Ekonomiczna, Kraków. Jakubowska A., 2015, Zaufanie podstawa wspótpracy banku i samorzadu lokalnego, Prace Naukowe Uniwersytetu Ekonomicznego we Wrocławiu, nr 403, s. 77-86.

Majka J., 2016, Wspólnie z SGB budujmy kapitał społeczny, Nowoczesny Bank Spółdzielczy, nr 1, s. 54-55. 
Masiukiewicz P., 2007, Zaufanie publiczne jako wartość w banku, Bank i Rolnictwo, nr 2, s. 3-5.

Nowacka A., 2016, Postrzeganie społecznej odpowiedzialności biznesu w bankach spółdzielczych przez ich klientów, Ekonomia Społeczna, nr 2, s. 60-70.

Nowacka A., Szewczyk-Jarocka M., Kaczmarczyk P., Grzywacz J., 2017, Banki spółdzielcze w społecznej gospodarce rynkowej, Wydawnictwo Naukowe Państwowej Wyższej Szkoły Zawodowej w Płocku, Płock.

Nowakowska-Krystman A., 2006, Siła klientów w negocjacjach z polskimi bankami spółdzielczymi, [w:] Stefański M. (red.), Banki spółdzielcze w Polsce po 1989 roku, Wydawnictwo Wyższej Szkoły Humanistyczno-Ekonomicznej we Włocławku, Włocławek, s. 61-74.

Rosa A., 2009, Rola banków spółdzielczych w finansowaniu działalności MSP, Ekonomiczne Problemy Usług, nr 34, s. 112-117.

Smoleń M., 2005, Spółdzielczość bankowa w lokalnym środowisku gospodarczym, Bank Spółdzielczy, nr 10 , s. $10-13$.

Strzelecki A., 2008, Aspekty etyczne działalności banków spółdzielczych, [w:] Stefański M. (red.), Perspektywy rozwoju bankowości spółdzielczej w Polsce, Wydawnictwo Wyższej Szkoły Humanistyczno-Ekonomicznej we Włocławku, Włocławek, s. 109-133. 